\title{
2005-2018 Sosyal Bilgiler Öğretim Programları ve Sosyal Bilgiler Ders Kitaplarında Yer Alan Seyahatnamelerin Değerlendirilmesi
}

Ülkü Yanc1 ${ }^{1}$
Nagihan Evci ${ }^{2}$
Type/Tür:

Research/Araştırma

Received/Geliş Tarihi: April 20/

20 Nisan 2020

Accepted/Kabul Tarihi:

September 17/ 17 Eylül 2020

Page numbers/Sayfa No: $371-391$

Corresponding

Author/Iletişimden Sorumlu

Yazar: u.yancii@gmail.com

\section{$\checkmark$ iThenticate}

This paper was checked for plagiarism using iThenticate during the preview process and before publication. / Bu çalışma ön inceleme sürecinde ve yayımlanmadan önce iThenticate yazılımı ile taranmıştır.

Copyright@ 2017 by Cumhuriyet University, Faculty of Education. All rights reserved.

\section{Öz}

Bu araştırmada, 2005 ve 2018 sosyal bilgiler öğretim programları ve sosyal bilgiler ders kitaplarında seyahatnamelerin kullanım durumlarının belirlenmesi amaçlanmıştır. Çalışmada nitel araştırma yöntemlerinden betimsel analizi tekniği kullanılmıştır. Araştırmadan elde edilen bulgular neticesinde, sosyal bilgiler programındaki seyahatnamelerin kullanımı ve seyahatnamelerle ilişkilendirilen kazanımların belirlenmesinin yanı sıra hedeflere ulaşmak için hangi seyyahların hangi seyahatnamelerinin ders kitaplarında kullanıldığı da tespit edilmiştir. 2005 sosyal bilgiler öğretim programında seyahatnamelerin doğrudan kullanıldığı iki kazanıma yer verilirken, 2018 sosyal bilgiler öğretim programında ise üç kazanıma yer verildiği saptanmıştır. Doğrudan kullanılan kazanım sayısının bir önceki programa göre arttığı belirlenmiştir. Araştırmada; 2005 öğretim programına göre 2018 öğretim programında seyahatname kullanımının artırılmasının ders kitaplarına da yansıdığı ve bu durumun seyahatnamelerin önemini artırdığı söylenebilir. Çalışmada ulaşılan bulgulardan hareketle uygulamaya ve ileri araştırmalara yönelik öneriler getirilmiştir.

Anahtar Kelimeler: Sosyal bilgiler, öğretim programları, edebi ürün, seyahatname, seyyah.

\section{Suggested APA Citation/Önerilen APA Atıf Biçimi:}

Yanc1, Ü., \& Evci, N. (2021). 2005-2018 Sosyal bilgiler öğretim programları ve sosyal bilgiler ders kitaplarında yer alan seyahatnamelerin değerlendirilmesi. Cumhuriyet International Journal of Education, 10(1), 371-391. http://dx.doi.org/10.30703/cije.723728

\footnotetext{
${ }^{1}$ Dr. Öğr. Üyesi, Sivas Cumhuriyet Üniversitesi, Eğitim Fakültesi, Türkçe ve Sosyal Bilimler Eğitimi Bölümü, Sivas/Türkiye

Asst. Prof. Dr., Sivas Cumhuriyet University, Faculty of Education, Department of Turkish and Social Sciences Education, Sivas/Türkiye

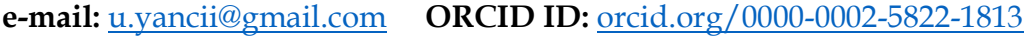

2 Doktora Öğrencisi, Sivas Cumhuriyet Üniversitesi, Eğitim Bilimleri Enstitüsü, Sivas/ Türkiye Phd Student, Sivas Cumhuriyet University, Department of Social Studies Education, Sivas/ Turkey e-mail: evcinagihan@gmail.com ORCID ID: orcid.org/0000-0002-1001-3126
} 


\title{
Evaluation of Travel Books in Social Studies Curriculum and Social Studies Textbooks for 2005-2018
}

\begin{abstract}
In this study, it was aimed to determine the usage status of travel books in 2005 and 2018 social studies curricula and social studies textbooks. Descriptive analysis technique, one of the qualitative research methods, was used in the study. As a result of the findings obtained from the research, it was determined that the travel books used in the social studies program and the gains associated with the travel books, as well as which travel books were used in the textbooks to reach the goals. In the 2005 social studies curriculum, two achievements were used in which the travel books were used directly, while in the 2018 social studies curriculum, three achievements were found. It has been determined that the number of gains directly used has increased compared to the previous program. In the study; According to the 2005 curriculum, it can be said that increasing the use of travel books in the 2018 curriculum is reflected in the textbooks and this situation increases the importance of travel books. Based on the findings reached in the study, suggestions for application and advanced research have been made.
\end{abstract}

Keywords: Social studies, curriculum, literary product, travel book, traveler.

\section{Giriş}

Sosyal bilgiler; edebiyat, hukuk, sosyoloji, psikoloji, antropoloji, tarih, coğrafya, ekonomi ve siyaset bilimi gibi sosyal bilim alanlarından yararlanarak yaşama yönelik bilgilerin öğretilmesini hedefleyen bir öğretim programıdır (MEB, 2005). Sosyal bilgiler, bu disiplinlere ait içerik ve yöntemler yardımıla elde edilen verileri kaynaştırarak kullanmakta (Öztürk, 2009), bireylerin toplumsal ve fiziki çevrelerine yönelik ilişkilerini zaman boyutu içerisinde ele almaktadır (Şimşek, 2006).

Sosyal bilgiler dersi öğretim programının temel amacı; bireylere vatandaşlık konularıyla ilgili bilgi, beceri, değer ve tutumları kazandırmaktır. Ayrıca bireylerin, görev ve sorumluluklarının bilincinde olmalarını, toplumsal problemleri bağımsız ve işbirliğine dayalı bir yöntemle çözebilmelerini, başkaları tarafından önerilen çözümlere eleştirel ve yaratıcı bir şekilde karşlık verebilmelerini öğretmek de sosyal bilgilerin hedefleri arasında yer almaktadır (Aykaç, 2007). Sosyal Bilgiler dersi, hedefi ve amaçlarının öneminden dolayı Cumhuriyet'in ilk yıllarından itibaren Milli Eğitim müfredatlarında temel dersler arasında yer almaktadır (Öztürk, 2009).

Bu bağlamda geçmişten günümüze kadar öğretim programındaki kazanımların daha kolay aktarılması ve öğrenciler tarafından öğrenilmesi için çeşitli yöntem, teknik ve materyallere başvurulmuştur. Ders kitaplarında kullanılan seyahatname, destan, yazıt, biyografi, şiir gibi sözlü ve yazılı edebi ürünler de bu materyaller arasında yer almaktadır (İlhan, 2016). Sosyal bilgiler dersi içerik olarak insan ve insan ilişkilerini konu aldığı için insanların duygu, düşünce ve hayallerini anlatmalarına olanak tanımaktadır. Bu sebeple edebi ürünlerin kullanılmasının gerekliliği ortaya çıkmakta ve bu durum edebiyat ile sosyal bilgiler disiplinini ortak bir hedefte buluşturmaktadır (Çetişli, 2006). Edebi ürünlerin öğretim ortamlarında etkili bir biçimde kullanılmalarıla öğrencilerde; anlama, yorumlama, empati kurma becerileri geliştirilirken analiz yapma ve farklı bakış açısı geliştirme davranışları da kazandırılmaktadır. Ayrıca millî ve evrensel değer yargılarının oluşturulmasına da katkı sağlamaktadır. Bu aşamada tarih ve coğrafya disiplinleri ile sosyal bilgilerin arasındaki ortak payda ortaya çıkmaktadır. Bu durumlar sosyal bilgilerin diğer 
disiplinlerle aralarında bir bağ olduğunun somut göstergesidir. Oluşan bağ sonucu farklı edebi ürünlerin kullanımı önemli kabul edilmektedir (Gowan ve Guzzetti, 2003). $\mathrm{Bu}$ açıdan sosyal bilgiler dersi içerisinde kullanımı gerekli görülen edebi ürünlerden biri de seyahatnamelerdir.

Edebi ürünler arasında yer alan seyahatnameler; özellikle tarihsel konuların öğretimi esnasında öğrencide tarihi bilinç ve düşünce yapısı oluşturarak derslerin verim ve etkililik derecesini artırmaktadır. Aynı zamanda seyahatnamelerin ders sürecinde kullanılmasıyla birlikte işlenen konu somutlaştırılarak, konunun öğrenci tarafından daha kolay anlaşılması sağlanmaktadır. Seyahatnamelerin çeşitli yöntem ve tekniklerle birlikte kullanılması ise programda yer alan; beceri, değer ve kazanımların öğretiminde vatandaşlık becerilerinin geliştirilmesinde kolaylık sunacaktır (Ata, 2013). Aynı zamanda kültürel deneyimleri, coğrafi ve tarihi bilgileri sınıf ortamında öğrencilere kolaylıkla aktaracağı için seyahatnameler kıymetli bir öğretim materyali olarak kabul edilmektedir (Şimşek, 2015).

Çeşitli amaçlar gözetilerek gerçekleştirilen seyahatlerin kaleme alınması ile ortaya çıkan edebi ürünlere seyahatname adı verilir. "Seyahat", Arapça da gezi anlamında ve "name" ise Farsça da mektup, risale anlamında kullanılmaktadır. Arapça ve Farsça bu kelimelerin birleşiminden doğan "seyahatname", gezi mektubu ya da gezi yazısı anlamina gelmektedir (Yazıc1, 2009).

Seyahatnameleri kaleme alan, gezileri bizzat gerçekleştirmiş olan kişilere seyyah denir. Seyyahlar, gezileri sırasında karşılaştıkları yeni yerlerin coğrafi, tarihi ve sosyal yapılarına ait özelliklerini kaydeder ve ülkelerine döndüklerinde halkı bilgilendirmek maksadıyla bu notları tutmuşlardır. Coğrafi açıdan yeni yerlerin keşfi ve uzak ülkelerin merak edilmesi insanları bu yerleri araştırmaya yönlendirmiş ve araştırmalar neticesinde kaleme alınan seyahatnameler sayesinde ise insanlar meraklarını gidermişlerdir (Maden, 2008). Çünkü seyyahlar, seyahatnamelerinde gezmiş oldukları toplumların günlük yaşamları ve gelenek göreneklerine yer vermişlerdir. Aynı zamanda toplumların siyasi yapıları, adet, inanış, gelenek -görenek ve yaşam biçimleri gibi birçok konuda kıymetli bilgiler sunmuşlardır. Bu özellikleri dolayısıyla seyahatnameler dünya üzerinde geçmişten günümüze yaşamış olan toplumlar hakkında bilgi verici bir rol üstlenmiştir (Yazıcı, 2009). Bu açıdan seyahatnameler doğru değerlendirildiğinde, devlet kayıtlarında bazen bulunmayan hususları aydinlatmakta bulunsa da yetersiz olan bilgileri tamamlamakta ve tarihi açıdan da birincil kaynak olarak nitelendirilmektedir (Yanc1, 2016). Bu nedenle sosyal bilgiler öğretim programlarında da geniş yer bulmuştur.

Sosyal bilgiler öğretim programlarında seyahatnamelerin kullanımı üzerine yapılan çalışmalar incelendiğinde; sosyal bilgiler dersinde Evliya Çelebi Seyahatnamesinin kullanılabilirliği (Çelik, 2016), Cumhuriyetin ilk yıllarından bugüne kadar yürütülmüş olan sosyal bilgiler öğretim programları içerisinde seyahatnamelerin kullanım durumu (Yakar, 2013), sosyal bilgiler dersi kapsamında hâlihazırda kullanılan ders kitaplarında seyahatnamelerin ne şekilde yer aldığı (Oruç ve Aygün, 2018), Evliya Çelebi Seyahatnamesi içeriğinin sosyal bilgiler dersi 5.-7. sınıf öğretim programında bulunan kazanımlara göre incelenmesi (Çelik ve Çetin, 2019), sosyal bilgiler dersi öğretim programında seyahatnamelere ne derece yer verildiği (Ata, 2013), seyahatnamelerin tarihi, önemi ve sosyal bilimlerde kullanımının ne şekilde olduğu (Şirin, 2020) konularını ele alan çalışmalara rastlanmıştır. Fakat 2005 ve 
2018 sosyal bilgiler öğretim programları ve programlara yönelik hazırlanan ders kitaplarının seyahatname kullanımı açısından değerlendirildiği herhangi bir çalışmaya rastlanmamıştır.

\section{Araştırmanın Amacı ve Önemi}

$\mathrm{Bu}$ araştırmanın amacı, 2005 ve 2018 sosyal bilgiler öğretim programları ve sosyal bilgiler ders kitaplarında seyahatnamelerin kullanım durumlarının belirlenmesi ve programlar arası değişimin anlaşılmasıdır. 2005 ve 2018 sosyal bilgiler öğretim programlarına göre ders kitaplarındaki seyahatname kullanım durumlarındaki değişimlerin belirlenmesinin alana katkı sağlayacağı düşünülmektedir.

\section{Sinirlılıklar}

Araştırma kapsamında iki önemli sınırlılığa yer verilmiştir. Bunlardan ilki, 2005 ve 2018 sosyal bilgiler öğretim programları kullanılmıştır. İkincisi, 2005 ve 2018 sosyal bilgiler öğretim programlarına ait ders kitaplarından, 4. ve 5. sınıf ders kitaplarında seyahatnamelerin doğrudan kullanımı ile ilgili herhangi bir kazanım yer almadığı için yalnızca 6. ve 7. sınıf ders kitapları kullanılmıştır.

Bu çalışma ile aşağıdaki sorulara cevap aranmıştır:

1. 2005 ve 2018 Sosyal Bilgiler Öğretim Programı' nda seyahatnamelere yeterli ölçüde yer verilmiş midir?

2. Sosyal Bilgiler Öğretim Programlarında seyahatnamelere ilişkin doğrudan yer verilen kazanımlar nelerdir?

3. Sosyal bilgiler öğretim programlarında seyahatnamelere ilişkilendirilen kazanimlar nelerdir?

4. 2005 ve 2018 Sosyal Bilgiler Öğretim Programı'na göre düzenlenen ders kitaplarında seyahatnamelere ne ölçüde yer verilmiştir?

\section{Yöntem}

2005 ve 2018 sosyal bilgiler öğretim programları ve sosyal bilgiler ders kitaplarında seyahatnamelerin kullanım durumlarının belirlenmesinin amaçlandığı bu çalışma nitel araştırma deseni olarak tasarlanmış ve betimsel araştırma yöntemi kullanılarak gerçekleştirilmiştir. Nitel araştırma, var olan olgu ve olayların müdahale edilmeksizin, gerçekçi bir tavırla belirlenmesini sağlamaktadır (Yıldırım ve Şimşek, 2011). Betimsel araştırma yöntemi, araştırma problemine yönelik mevcut durumu belirlemeyi, problemi tasvir ederek anlamayı amaç edinen, hem nicel hem de nitel araştırmalarda kullanılan bir araştırma yöntemidir (Arıkan, 2011).

\section{Verilerin Toplanması}

Çalışma verilerinin toplanması için doküman incelemesi yöntemine başvurulmuştur. Doküman incelemesi, araştırılması gereken olgu, olaylara yönelik farklı kaynak ve dokümanların kullanılıp analiz edilmesini kapsamaktadır (Yıldırım ve Şimşek, 2011). Çalışma verileri için, 2005-2018 sosyal bilgiler dersi öğretim programları Milli Eğitim Bakanlığı (MEB) tarafından onaylanan, belirlenmiş yıllar içerisinde kullanımda olan MEB ve Ekoyay yayınlarına ait 2019 yılı sosyal bilgiler 6. ve 7. sinıf ders kitapları ile yine MEB ve Anittepe yayınlarına ait 2010 ve 2013 yıllarına ait sosyal bilgiler 6. ve 7 . sınıf ders kitapları doküman olarak kullanılmıştır. 


\section{Verilerin Analizi}

Doküman incelemesi ile elde edilmiş olan veriler betimsel analiz yöntemi kullanılarak incelemeye tabi tutulmuştur. Betimsel analiz, elde edilen bulguları düzenleyip yorumlayarak okuyucuya sunmaktadır. Bu amaç doğrultusunda ulaşılan veriler, öncelikle sistematik ve açık bir biçimde betimlenmekte daha sonra açıklanıp yorumlanarak bir takım sonuçlara ulaşılmaktadır (Yıldırım ve Şimşek, 2011). Bu kapsamda 2005-2018 sosyal bilgiler öğretim programları ve bu programlara yönelik oluşturulan ders kitapları sosyal bilgiler eğitimi alanında 3 öğretim üyesi ve 2 tane de sosyal bilgiler öğretmeni tarafından incelemeye tabi tutulmuştur.

\section{Bulgular}

Araştırmada 2005 ve 2018 Sosyal Bilgiler dersi öğretim programlarında ve sosyal bilgiler ders kitaplarında seyahatnamelerin yer alma durumu incelenmiştir. Ayrıca ders kitaplarında yer alan seyyahlar belirlenerek haklarında kısaca bilgiler de sunulmuştur. Elde edilen bulgular aşağıda başlıklar halinde sunulmuştur.

\section{2005 Sosyal Bilgiler Öğretim Programı ve Ders Kitaplarında} Seyahatnamelere İlişkin Bulgular

2005 sosyal bilgiler öğretim programında 8 öğrenme alanı yer almaktadır. Bu öğrenme alanları altında bulunan ünite içerikleri ve kazanımlar seyahatnamelerin kullanım durumları açısından incelenmiştir. Programda belirtilen ve seyahatnamelerin doğrudan kullanımını uygun gören kazanımlar belirlenerek Tablo 1'de verilmiştir.

Tablo 1

2005 Sosyal Bilgiler Öğretim Programında Seyahatnamelerin Kullanıldı̆̆ı Kazanımlar

\begin{tabular}{ccll}
\hline Sınıf & $\begin{array}{c}\text { Öğrenme } \\
\text { Alanı }\end{array}$ & \multicolumn{1}{c}{ Ünite } & \multicolumn{1}{c}{ Kazanım } \\
\hline 6. & Kültür ve & İpek Yolunda Türkler & $\begin{array}{l}\text { 1. Kazanım: Destan, yazıt ve diğer } \\
\text { belgelerden yararlanarak, Orta Asya ilk } \\
\text { Türk devletlerinin siyasal, ekonomik ve } \\
\text { kültürel özelliklerine ilişkin çıarımlarda } \\
\text { bulunur. }\end{array}$ \\
\hline 7. & $\begin{array}{c}\text { Kültür ve } \\
\text { Minıf }\end{array}$ & Türk Tarihinde Yolculuk & $\begin{array}{l}\text { 6. Kazanım: Seyahatnamelerden hareketle } \\
\text { Türk kültürüne ait unsurları örneklendirir. }\end{array}$ \\
\hline Sınıf & Miras & &
\end{tabular}

Tablo 1 incelendiğinde; 2005 sosyal bilgiler dersi öğretim programındaki öğrenme alanları içerisinde yer alan kazanımlardan seyahatnamelerle doğrudan ilişkili 2 kazanımın yer aldığı görülmektedir. Bunlardan ilki; 6. sınıfa yönelik 'Kültür ve Miras' öğrenme alanı içerisindeki ‘İpek Yolunda Türkler' ünitesinin 1. kazanımı ile 7. sınıfa yönelik 'Kültür ve Miras' öğrenme alanı içerisindeki 'Türk Tarihinde Yolculuk' ünitesine ait 6. kazanımdır. İlgili kazanımlar hakkında programda seyahatnamelerin kullanılmasını gerekli gören açıklamalar yapıldığı için bu kazanımlar, seyahatnamelerin doğrudan kullanıldığı kazanımlar arasında değerlendirilmiştir.

Programda yer alan diğer kazanımların bir kısmında tarihten ve günümüzden kanıt istenmesi, geçmiş ve günümüz hakkında çıkarım yaptırılması, örnek incelemelerin gerekli görülmesi ve verilen açıklamalarda bazı kazanımlar için belge ve 
kanıt kullanılabileceğinin belirtilmesi durumları yer aldığı için seyahatname kullanımı uygun hale gelmiştir. Bu doğrultuda programda seyahatname kullanımı belirtilmese de seyahatnamelerle ilişkilendirilebilecek kazanımlar belirlenmeye çalışılmış ve tespit edilen kazanımlar Tablo 2'de sunulmuştur.

2005 sosyal bilgiler programını içeren ve kullanımda olan Milli Eğitim Bakanlığ1 tarafından hazırlanmış olan 6. sınıf ders kitabı ile Anıttepe yayınlarına ait 7. sınıf sosyal bilgiler ders kitabında yer alan seyyahların seyahatlerine ilişkin metin örnekleri verilmiştir. Bu metinlere ait görseller Tablo 3 'te belirtilmiştir.

Tablo 2

2005 Sosyal Bilgiler Öğretim Programında Seyahatnamelerle İlişkilendirilen Kazanımlar

\begin{tabular}{|c|c|c|c|}
\hline Sinif & $\begin{array}{l}\text { Öğrenme } \\
\text { Alanı }\end{array}$ & Ünite & Kazanım \\
\hline $\begin{array}{c}5 . \\
\text { Sinif }\end{array}$ & $\begin{array}{l}\text { İnsanlar, } \\
\text { Yerler ve } \\
\text { Çevreler }\end{array}$ & Bölgemizi Tanıyalım & $\begin{array}{l}\text { 6. Kazanım: Kültürümüzün sözlü ve yazılı } \\
\text { ögelerinden yola çıarak, doğal afetlerin toplum } \\
\text { hayatı üzerine etkilerini örneklendirir. }\end{array}$ \\
\hline \multirow[t]{2}{*}{$\begin{array}{c}6 . \\
\text { Sinif }\end{array}$} & $\begin{array}{l}\text { Kültür ve } \\
\text { Miras }\end{array}$ & İpek Yolunda Türkler & $\begin{array}{l}\text { 5. Kazanım: Görsel ve yazılı materyallerden } \\
\text { yararlanarak İslamiyet'in ortaya çıkışı ve } \\
\text { yayılışını inceler. } \\
\text { 8. Kazanım: Örnek incelemeler yoluyla kutlama } \\
\text { ve törenlerimizdeki uygulamaların kültürümüzü } \\
\text { oluşturan unsurlarla ilişkisini değişim ve } \\
\text { süreklilik açısından değerlendirir. } \\
\text { 9.Kazanım: Orta Asya ilk Türk Devletleri ve } \\
\text { Türk-İslam Devletlerinin Türk kültür, sanat ve } \\
\text { estetik anlayışına katkılarına kanıtlar gösterir. }\end{array}$ \\
\hline & $\begin{array}{l}\text { Güç, Yönetim } \\
\text { ve Toplum }\end{array}$ & $\begin{array}{l}\text { Demokrasinin } \\
\text { Serüveni }\end{array}$ & $\begin{array}{l}\text { 2. Kazanım: Değişik dönem ve kültürlerde } \\
\text { demokratik yönetim anlayışının tarihsel } \\
\text { gelişimini tartısır. } \\
\text { 5. Kazanım: Türk tarihinde kadının konumu ile } \\
\text { ilgili örnekleri, kadın haklarının gelişimi } \\
\text { açısından yorumlar. }\end{array}$ \\
\hline \multirow[b]{2}{*}{$\begin{array}{c}7 . \\
\text { Sinif }\end{array}$} & $\begin{array}{l}\text { Külttür ve } \\
\text { Miras }\end{array}$ & $\begin{array}{l}\text { Türk Tarihinde } \\
\text { Yolculuk }\end{array}$ & $\begin{array}{l}\text { 2. Kazanım: Kanıtlara dayanarak Osmanlı } \\
\text { Devleti'nin siyasi güç olarak ortaya çıkışını } \\
\text { etkileyen faktörleri açılar. } \\
\text { 4. Kazanım: Osmanlı toplumunda hoşgörü ve } \\
\text { birlikte yaşama fikrinin önemine dayalı kanıtlar } \\
\text { gösterir. } \\
\text { 5. Kazanım: Şehir incelemesi yoluyla, Türk } \\
\text { külttür, sanat ve estetik anlayışındaki değişim ve } \\
\text { sürekliliğe ilişkin kanıtlar gösterir. }\end{array}$ \\
\hline & $\begin{array}{l}\text { Üretim, } \\
\text { Dağıtım ve } \\
\text { Tüketim }\end{array}$ & $\begin{array}{c}\text { Ekonomi ve Sosyal } \\
\text { Hayat }\end{array}$ & $\begin{array}{l}\text { 2. Kazanım: Kaynakların, ürünlerin ve ticaret } \\
\text { yolarının devletlerin gelişmesindeki önemine } \\
\text { tarihten ve günümüzden örnekler verir. } \\
\text { 3. Kazanım: Tarihten ve günümüzden örnekler } \\
\text { vererek üretim teknolojisindeki gelişmelerin } \\
\text { sosyal ve ekonomik hayata etkilerini } \\
\text { değerlendirir. } \\
\text { 4. Kazanım: Vakıfların çalışmalarına ve sosyal } \\
\text { yaşamdaki rolüne tarihten ve günümüzden } \\
\text { örnekler verir. }\end{array}$ \\
\hline
\end{tabular}


Tablo 2 incelendiğinde; 2005 sosyal bilgiler dersi öğretim programındaki öğrenme alanları içerisinde yer alan ve seyahatname kullanımını uygun gören kazanımlar belirlenmeye çalışılmıştır. İlgili tablodan anlaşılacağı üzere seyahatnamelerin kullanılabileceği 12 kazanım belirlenmiştir.

Tablo 3

6. ve 7. Sinıf Sosyal Bilgiler Ders Kitaplarında Yer Verilen Seyyahlara Ait Bilgi ve Görseller

\begin{tabular}{|c|c|}
\hline Seyyah & Seyyah Hakkında Bilgi \\
\hline $\begin{array}{c}1 . \\
\text { Bertrandon } \\
\text { de La } \\
\text { Broquière }\end{array}$ & $\begin{array}{l}\text { Fransız kökenli bir Hristiyan } \\
\text { olan Broquière, görev amacı } \\
\text { çımış olduğu seyahatlerde } \\
\text { Türkleri politik açıdan } \\
\text { incelemiş ve gözlemlerine } \\
\text { seyahatnamesinde } \\
\text { vermiştir (Eyice, 1975). }\end{array}$ \\
\hline $\begin{array}{c}2 . \\
\text { Lady } \\
\text { Montaqu }\end{array}$ & 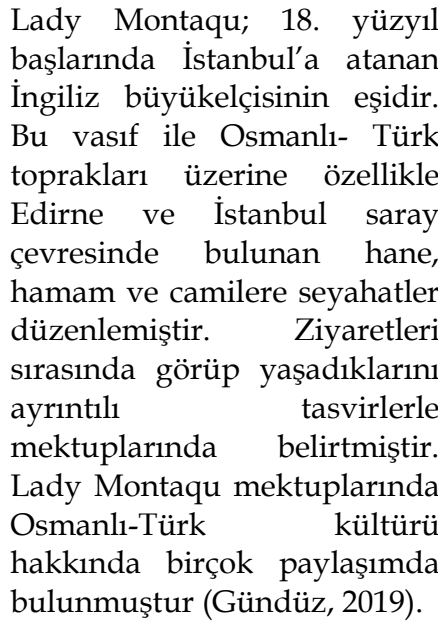 \\
\hline
\end{tabular}

Görsel 2. 7. Sinıf 3. Ünite, Türk Tarihinde Yolculuk, Seyyahlarla Gezinti İçerisinde Lady Montaqu Seyahatnamesine İlişkin Görsel s.99 (Anittepe)

1718'de bir sâre Tarkiye'de kalan Lady Montaqu (Lady Montek0) "Torkiye Mektuplar" adiı eseri ile âniodâr.

"Asil bir Turk kadin nasil giyinit, bunu og. renmok istorsin dogil mi? Iş̧te sana yaziyorum.

Onun arkasında dolama denilen bir gồmlok vardir. Dôgmeleri nohut iriliginde elmastan yapilmıştıt. Kemer gayet geniş ve baştan başa elmas. Gerdan dize kadar inen úç diżi inci ile strals. Dizilerden birinin ucunda Hint tavuğu yumurtası kadar bôyūk bir zûmrüt asił. Asil Tôrk kadınin kūpeleri takildiğ yere yakışacak degerdedir. Yôzūkler de óledir. Benim gördúgüm Türk kadınlarnndaki súslerin yarısı kiymetinde sûsū taşyyabilen Avrupalı bir kraliçe yoktur:" Lady Mantaqu, Tunkoye Moktuplan" s.77

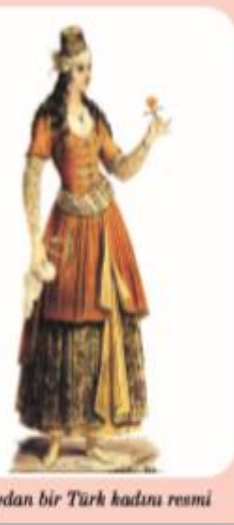

Saraydan bir Turh hadusu resmi

1433le Osmanlinin Rumeli topraklarni gezen Fransiz Seyyah Bertrandon de la Broquiete dan evinden çikmaz." demektedit. ntrandon de ba Broquiere in Denizaşan Seyahati, s.56.

Görsel 1. 7. Sinıf 3. Ünite, Türk Tarihinde Yolculuk, Seyyahlarla Gezinti İçerisinde Bertrandon de La Broquière Seyahatnamesine İlişkin Görsel s.98 (Antttepe)
Mantran; 1917 y1lında Paris'te doğmuştur. Fransa'da eğitimi sırasında birçok hocadan ders

3. almış ve Jean Sauvaget'nin

Robert dersleri ve öncülüğ̈ünde

Robert Osmanlı tarihi alanina

Mantran yönelmiştir. Görevleri sırasında İstanbul'a gelmiş ve İstanbul'u değişik açılardan ele alarak çalışmalarda bulunmuştur (Arıkan, 2003).
'Tûm esnaf Ioncalarnndaki Ĉyelerin aidatlan ile ustalann, çıak ve işcilerin yūkseltilme tôrenleri için verdikleri paralardan oluşan bir yardım sandığı bulunuyordu. 0 fonlar, loncayı yőneten komitenin emirlerine uygun olarak kullanilırd. Böylece, lonca esnafından biri hasta dūşâp de ailesinin gereksinimlerini karş̧layamaz olunca ona bir yardım eli uzanırd. Is hacmi azalıp bir işsizlilk donemi açıldığında da aynı yola başvururlard. Loncaların gerçek bir dayanışma ruhu sergilediklen yadsinamaz."

Robert Mantran, istanbul' da Gündeliki Hayat, s. 74.

Görsel 3. 7. Sinıf 3. Ünite, Türk Tarihinde Yolculuk, Seyyahlarla Gezinti İçerisinde Robert Mantran Seyahatnamesine İlişkin Görsel s.101 (Anttepe) 


\begin{tabular}{|c|c|c|}
\hline $\begin{array}{c}4 . \\
\text { Jan Potocki }\end{array}$ & 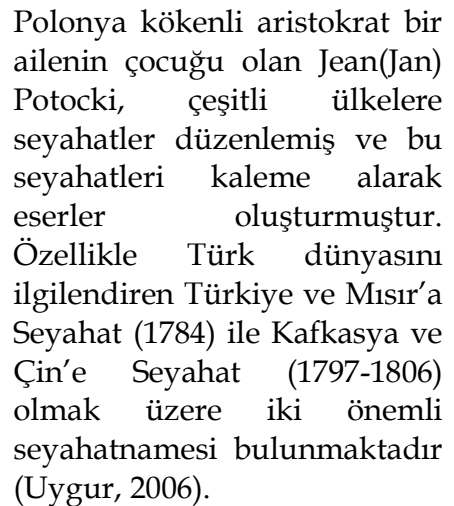 & 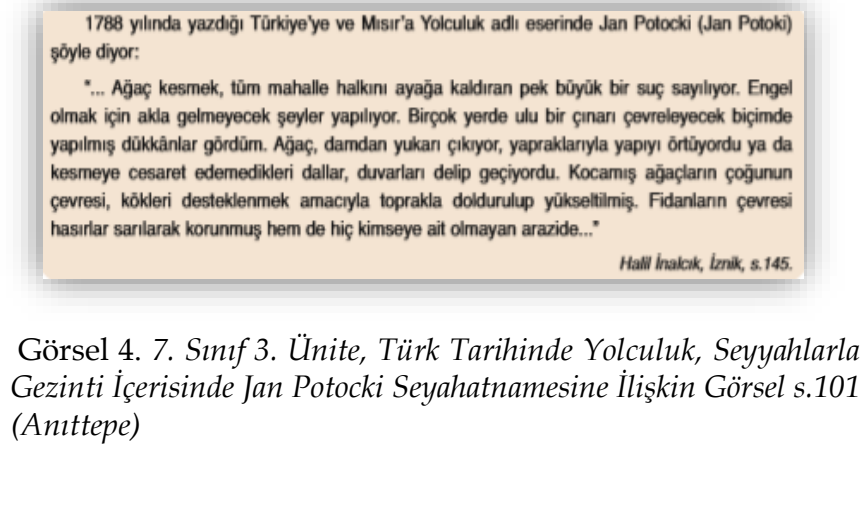 \\
\hline
\end{tabular}

Tablo 3 incelendiğinde; 2005 sosyal bilgiler öğretim programını içeren sosyal bilgiler 7. sinıf ders kitabında faydalanılan; Bertrandon de La Broquière, Lady Montaqu, Robert Mantran ve Jan Potocki' nin ülkemizle bağlantılarını anlayabilmek adına bu seyyahlara ait bilgilere yer verilmiştir. 6 . sınıf kitabında seyyahlara rastlanmadığı için yukarıdaki tabloda 6. sınıfa ait herhangi bir bilgiye yer verilmemiştir. Ayrıca bu seyyahların seyahatnamelerine ait metin örneklerinin görselleri de tabloda belirtilmiştir.

\section{2018 Sosyal Bilgiler Dersi Öğretim Programı ve Ders Kitaplarında Seyahatnamelere İlişkin Bulgular}

Çalışmada 2018 Sosyal Bilgiler öğretim programında bulunan yedi öğrenme alanının altında yer alan ünite içerikleri ve kazanımlar seyahatnamelerin kullanım durumları açısından incelenmiştir. Programda belirtilen ve seyahatnamelerin doğrudan kullanımını uygun gören kazanımlar belirlenmiş ve Tablo $4^{\prime}$ te ele alınmıştır.

Tablo 4

2018 Sosyal Bilgiler Öğretim Programında Seyahatnamelerin Kullanıldı̆̆ı Kazanımlar

\begin{tabular}{ccll}
\hline Sınıf & $\begin{array}{c}\text { Öğrenme } \\
\text { Alanı }\end{array}$ & \multicolumn{1}{c}{ Ünite } & \multicolumn{1}{c}{ Kazanım } \\
\hline $\begin{array}{c}\text { 6. } \\
\text { Sınıf }\end{array}$ & $\begin{array}{c}\text { Kültür ve } \\
\text { Miras }\end{array}$ & İpek Yolunda Türkler & $\begin{array}{l}\text { 1. Kazanım: Orta Asya'da kurulan ilk Türk } \\
\text { devletlerinin coğrafi, siyasal, ekonomik ve } \\
\text { kültürel özelliklerine ilişkin çlkarımlarda } \\
\text { bulunur. }\end{array}$ \\
\hline 7. & $\begin{array}{c}\text { Kültür ve } \\
\text { Miras }\end{array}$ & Türk Tarihinde Yolculuk & $\begin{array}{l}\text { 5. Kazanım: Osmanlı kültür, sanat ve estetik } \\
\text { anlayışına örnekler verir. }\end{array}$ \\
\cline { 2 - 5 } Sinıf & $\begin{array}{c}\text { Üretim, } \\
\text { Dağıtım ve } \\
\text { Tüketim }\end{array}$ & Ekonomi ve Sosyal Hayat & $\begin{array}{l}\text { 4. Kazanım: Tarih boyunca Türklerde } \\
\text { meslek edindirme ve meslek etiği } \\
\text { kazandırmada rol oynayan kurumları tanır. }\end{array}$ \\
\hline
\end{tabular}

Tablo 4 incelendiğinde; 2018 sosyal bilgiler öğretim programındaki öğrenme alanları içerisinde yer alan ünite içerikleri ve kazanımlardan seyahatnamelerle doğrudan ilişkili olan 3 kazanıma yer verildiği anlaşılmaktadır. İlgili kazanımlar hakkında programda seyahatnamelerin kullanılmasını gerekli gören açıklamalar yapıldığı için bu kazanımlar, doğrudan kullanılan kazanımlar arasında değerlendirilmektedir. 
Programda yer alan diğer kazanımların yap1 itibariyle seyahatname kullanımını uygun hale getirdiği sonucuna varıldığı için 2018 programında seyahatname kullanımı doğrudan belirtilmese de seyahatnamelerle ilişkilendirilebilecek kazanımlar tespit edilmiş ve Tablo 5'te sunulmuştur.

Tablo 5

2018 Sosyal Bilgiler Öğretim Programında Seyahatnamelerle İlişkilendirilen Kazanımlar

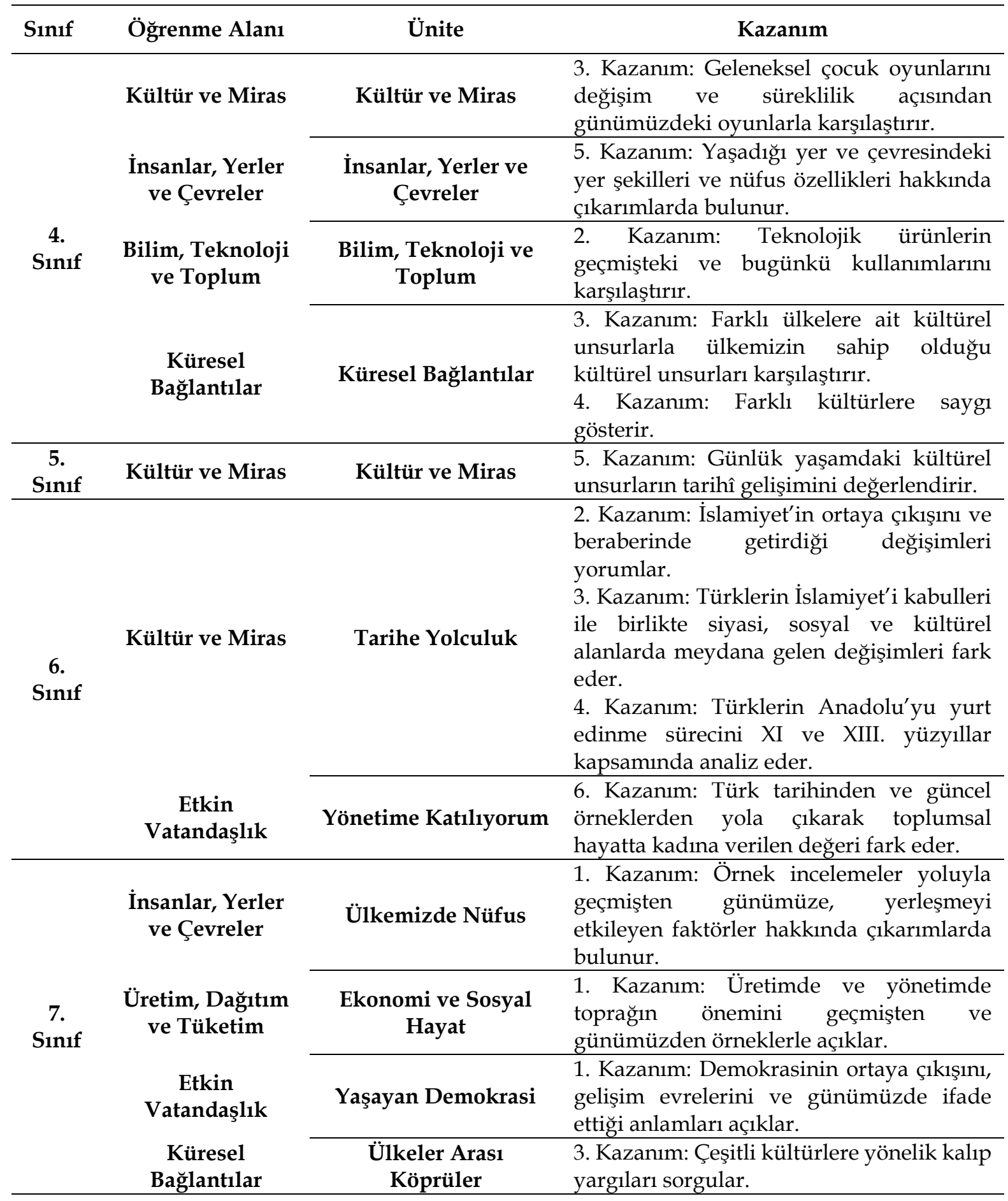

Tablo 5 incelendiğinde; 2018 sosyal bilgiler dersi öğretim programındaki öğrenme alanları içerisinde yer alan ve seyahatnamelerle ilişkilendirilen 14 kazanım 
olduğu görülmektedir. 2018 sosyal bilgiler programını içeren ve kullanımda olan MEB ve Ekoyay yayınlarına ait 6. ve 7. sosyal bilgiler ders kitaplarında bazı seyyahların seyahatlerine ilişkin metin örnekleri verilmiş ve bu metinlere ait görseller Tablo $6^{\prime} \mathrm{da}$ belirtilmiştir.

Tablo 6

6. ve 7. Sinuf Sosyal Bilgiler Ders Kitaplarnda Yer Verilen Seyyahlara Ait Bilgi ve Görseller

\begin{tabular}{|c|c|c|}
\hline Seyyah & Seyyah Hakkında Bilgi & Görsel \\
\hline$\stackrel{1 .}{\text { İbn-i Fadlan }}$ & $\begin{array}{l}\text { İbn-i Fadlan, elçilik görevi } \\
\text { ile seyahate çıkmış bu } \\
\text { süreçte uğramış olduğu } \\
\text { Türk kabilelerinin idari } \\
\text { yönleri, dinleri, gelenek- } \\
\text { görenekleri ve hukukları } \\
\text { hakkında bilgiler vermiştir. } \\
\text { Ayrıca gitmiş olduğu kabile } \\
\text { sakinleriyle iletişim } \\
\text { kurarak onlara sorular } \\
\text { sormuş ve onların } \\
\text { düşüncelerini anlamaya } \\
\text { çalışmıştır. Türkler dışında } \\
\text { Oğuzlar, Bulgarlar ve } \\
\text { Ruslar hakkında da bilgiler } \\
\text { vermiş, seyahatnamesinde } \\
\text { tüm notlarını kayıt altına } \\
\text { almıştır (Şeşen, 2012). }\end{array}$ & 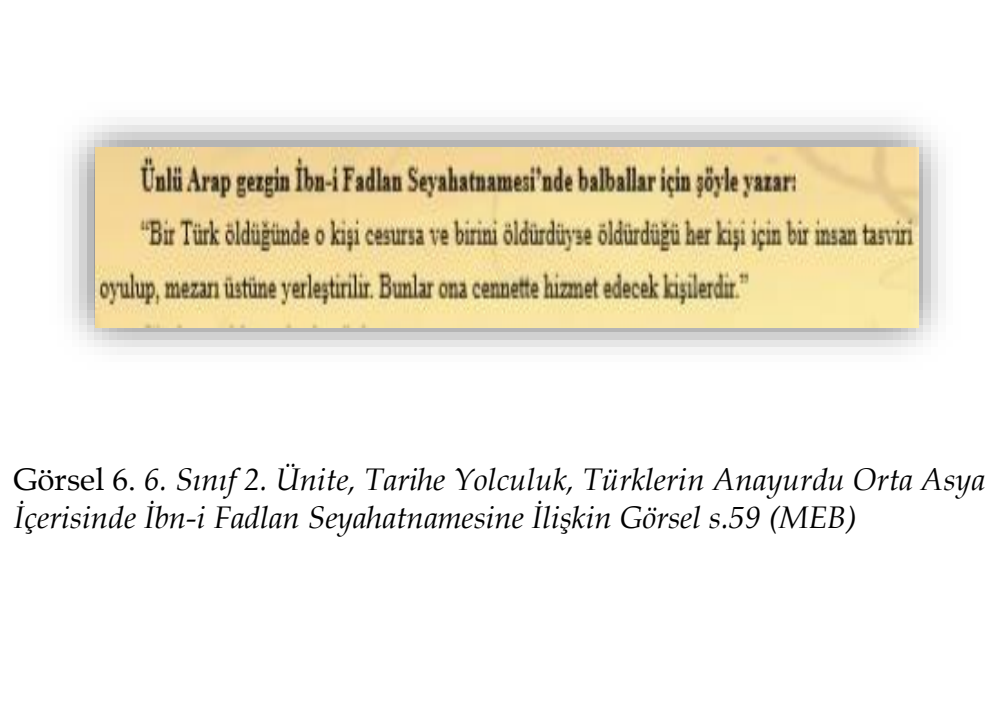 \\
\hline $\begin{array}{c}2 . \\
\text { Evliya Çelebi }\end{array}$ & 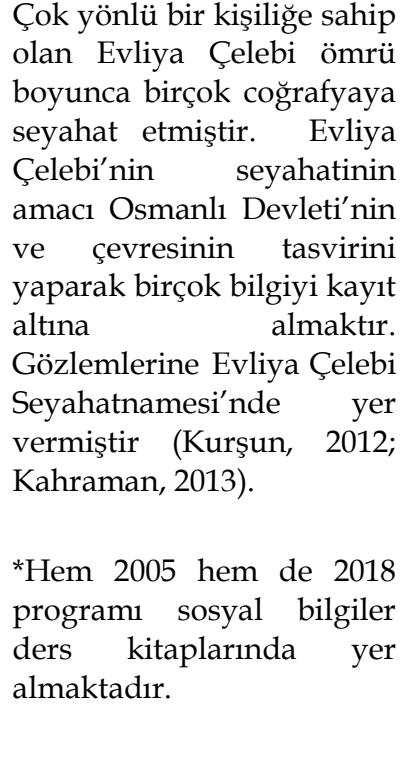 & 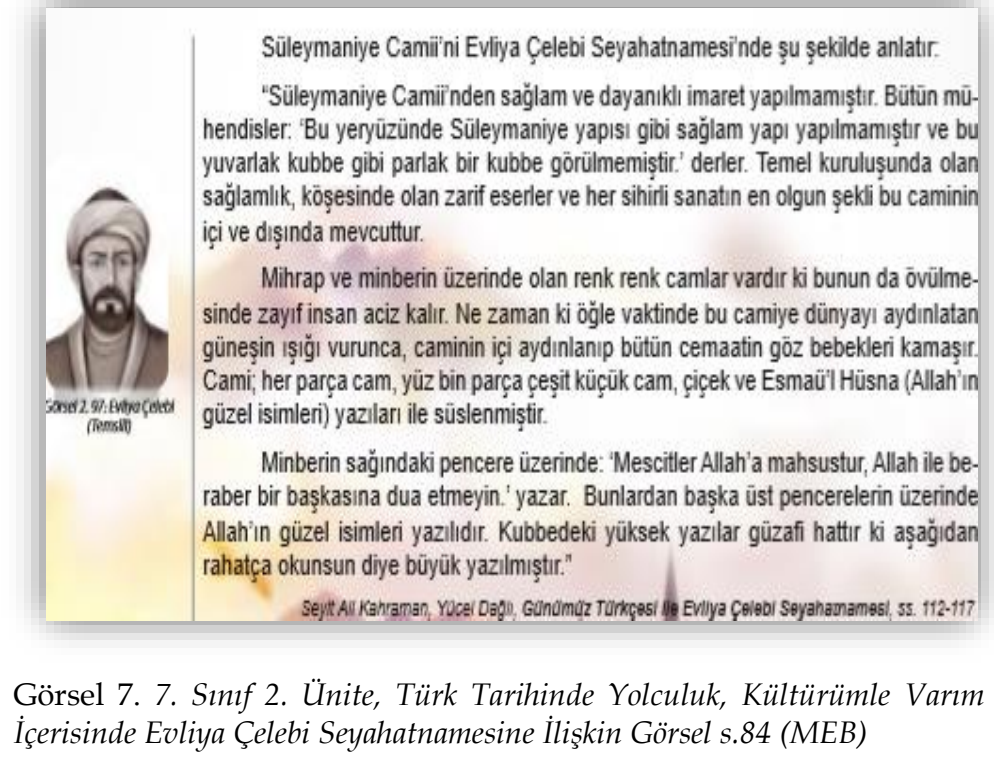 \\
\hline
\end{tabular}


Orta Çağ'ın en büyük seyyahı İbn-i Battuta birçok coğrafyayı gezmiş ve seyahatleri $29 \quad$ y1l sürmüştür. Seyahatleri sırasında pek çok coğrafyaya ve bu coğrafyalarda bulunan ülkelere ait özelliklere 3. dikkat çekmiş ve bu İbn-i özellikleri kayı altına Battuta almıştır. Tutmuş olduğu kayıtları birleştirerek seyahatnamelerini oluşturmuştur (Altıntaş, 2019).

*Hem 2005 hem de 2018 programı sosyal bilgiler ders kitaplarinda yer almaktadır.
Türkmenlerin yagadillan her vilayette, her gehirde vo her kồde bulunan Ahiler belar ve unat ahibi gençerin olug̣turduğg bir tür cemijettix. Bunlar birbirleriyla çole ala bir dayanugma içindedirler. Her birinin halk içinde muteber bir medeği vardr. Memleketlerine gelen yabancilarn yalan bir ilgi göoterir, onların yijecek vo içecelderini temin oderler. Öto yandan yagadalan yerlerdeki zorbalan da yola getiritles. Ahilerin bir arayz gelerek olug̣turduğa bu cemiyete firtivvet (genclik) adı verilir.

İni Battuta, Bĭgük Dërya Syahataamei, ,2.204

Görsel 8. 7. Sınıf 5. Ünite, Ekonomi ve Sosyal Hayat, Meslek Edindiren Kurumlar İçerisinde İbn-i Battuta Seyahatnamesine İlişkin Görsel s.166 (Ekoyay)
Ogier Ghislain de Busbecq, Osmanlı Devleti'nin fetihleri üzerine I. Ferdinand tarafindan Avusturya- Osmanlı 4. Devleti barışı için İstanbul'a Ogler gönderilmiştir. Busbecq Chirlain De görevi sürecinde Osmanlı Busbecq Devleti'ni dikkatle gözlemleyerek notlar almıştır. Bu mektupların üçünü İstanbul'dayken yazmıştır (Busbecq, 2005).
İasabul' 2 doğru ilerlodiğimiz aurada, mevvim lạ̣ olmasına rağmen lale, sümbül, nergis gibi çiçolderin açmig olduğunu hayrecte gördäk Lalelerin fazla bir leolcuau ofmamalda beraber görünüglerinin güzelliği ve renllerinin çeg̣itliliğ̈ine hayran olmamak mümkān değildir. Türłler çiçeğe aģın derecede düglkündūrler. Gürel bir çiçek için bǔyül milktarda para vermelcten çelainmezler. Bunlan çoğu defa bana hodiye ediyorlards.

Ogler Ghislain De Burbucq (Ogler Githye de Busbok

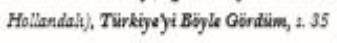

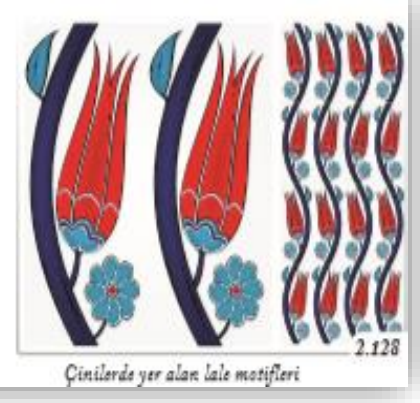

Görsel 9. 7. Sinıf 2. Ünite, Türk Tarihinde Yolculuk, Seyyahlarn Gözüyle Osmanl İçerisinde Ogier Ghislain de Busbecq Seyahatnamesine İlişkin Görsel s.84 (Ekoyay)
Alman bir diplomat olan Paul R. Krause, 1915 yılında Osmanlı ülkesinde bulunmuş ve burada gördüklerini bir kitapta anlatmıştır. Türklerin büyük ve saygın özellikleri 5. olduğunu dile getiren Paul R. seyyahin anlattıkları ve Krause özellikle Birinci Dünya Savaşı yıllarında Osmanlı ülkesinde bulunması savaş yılları Osmanlı ülkesinin bir yabancı gözüyle aktarılması açısından önem arz etmektedir (Krause, 2005).
Alman Seyyah Paul R. Krause (Paul Kravse) OsmanIı Devletīndeki konakları șöyle anlatır. "En zengin konağın basit bir evden farkı oda sayısı ve büyüklügü, halıların kalitesi ve duvarlar boyunca uzanan sedirlerin uzunluğudur. Bunun dıșında bütün evlerde aynı sadelik görülür; çerçevelenmiş birkaç Kur'an ayeti dıșinda duvarlarda resim ve mobilya yoktur. Sedirlerin boș köşelerinde üzerinde küçük eșyaların durduğu alçak bir sehpa görülūr. Yatak odalarında geniş gömme dolaplar bulunur. Çamaşırlar ve elbiseler burada durur, geceleri yere serilen yataklar, yorganlar, yastıklar sabahları toplanarak bu dolaplara saklanır." Paul R. Krause (Paul R. Kravse), Turkye 1915, s. 12

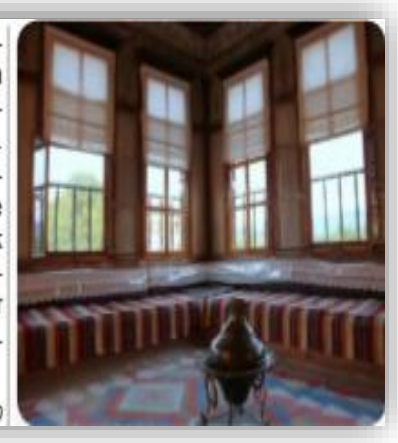

Görsel 10. 7. Sinıf 2. Ünite, Türk Tarihinde Yolculuk, Kültürümle Varım İçerisinde Paul R. Krause Seyahatnamesine İlişkin Görsel s.80 (MEB) 
Bir Protestan din bilimci olan 1573- 1578 yılları arasında Osmanlı Devleti topraklarinda

6. bulunmuştur. Sultan II.

Stephan Selim ve Sultan III. Murad Gerlach dönemine rastlayan Osmanlı ülkesinde günü gününe tuttuğu notlar daha sonra torunu olan Samuel Gerlach tarafindan 1674'te Frankfurt'ta basılmıştır (Gerlach, 2010).

Bir İngiliz doktor olan William Wittman, Misır'in Napolyon tarafından işgali sirasinda İngiltere tarafından Osmanlı

Devleti'ne yardım amacıyla 7. gönderilen askeri birlikte William görev yapmıştır. 1799- 1802 Wittman yilları arasinda bu vesile ile Osmanlı topraklarında bulunan Wittman, ülkesine dönüşünde gördüklerini ve yaşadıklarını aktarmıştır yazıya 1803).

(Wittman,
Gerlach (Gerlah), 1574'to Ramaran oona exdig̈indo minareleri aydunlaten tüm lambalarun kaldunlds-

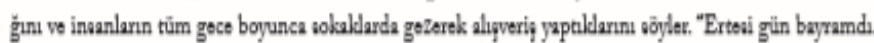

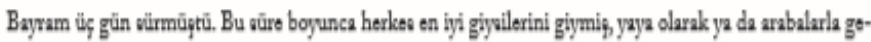

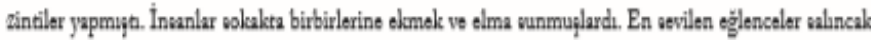
ve dōnmo dalap̣t. Birçok yerde alinceldar kurulmugtu

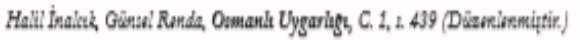

Görsel 11. 7. Sinı 2. Ünite, Türk Tarihinde Yolculuk, Seyyahların Gözüyle Osmanlı İcerisinde Seyyah Gerlach Gözlemlerine İlişkin Görsel s.88 (Ekoyay)

\begin{abstract}
Türk evleri ve iç düteni dildkate değer. Everin içi ve odalar genellikle gōoterį̣li sûalerle dolu, tavanla-

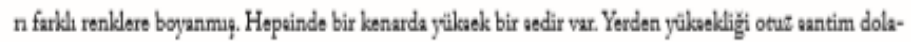
ynda, boyu da bir buçuk ilki metre kadar. Bu sodirin üzerine laumą̧a kapla ya da saten kapls quilteler konuyor, bir uçtan bir ucs yastalar diziliyor. Kosintisiz bir sedir havas yaratilmaya çalıgliyor. Yere güztel bir hala ya da kílim seriliyor. Pencereler kafeali ama camana. Mobilyalar arasinda ne masa ne de asndalyeler var, aslinda onlara gerçekten ihtiyaç da yok.
\end{abstract}

Wiliam Wittman (Vilyum Vitman, Ingrilis), Osmanadya Yolculak 1799-1500-1501, : 9

Görsel 12. 7. Sinıf 2. Ünite, Türk Tarihinde Yolculuk, Seyyahların Gözüyle Osmanlı İçerisinde Seyyah William Wittman Seyahatnamesine İlişkin Görsel s.86 (Ekoyay)
Bir Macar araştırmacı olan Bela Horvath, 1913 yılında Birinci Dünya Savaşı'ndan hemen önce Osmanlı 8. ülkesini ziyaret ederek Bela Ankara, Konya, Karaman, Horvath Niğde, Nevşehir gibi Anadolu'nun pek çok şehrini ziyaret etmiş, Türk kültürünü bizzat yaşayarak hayranlığını dile getirmiştir (Horvath, 2010).

İngiliz gezgin, kolonist, şair ve çevirmen olan Sandays, 1610 y1lında seyahatlerine başlamış ve ilk olarak Fransa'ya gitmiştir. Daha sonra İtalya, Venedik 9. yolunu kullanarak

George Konstantinopolis'e ve
Sandays oradan Osmanlı Devleti'ne geçmiştir. Sonrasında Misır, Filistin, Kıbris, Sicilya, Napoli ve Roma'ya gitmiştir. Gitmiş olduğu ülkeler hakkında notlar tutmuştur (Ellison, 2002).

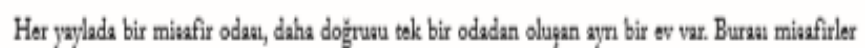

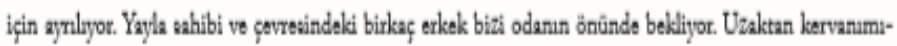

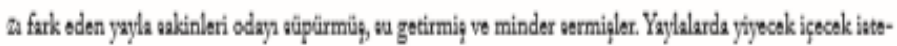
meniz gerekmiyor, onlar kendiligginden bunlan aize ikram ediyorlar. Türk halla ne kadar da iyi kalpli, miufirperver ve içten.

Bita Horoath (Boit Horvit, Macar), Anadolu 1913, a 39

Görsel 13. 7. Sinıf 2. Ünite, Türk Tarihinde Yolculuk, Seyyahlarn Gözüyle Osmanlı İçerisinde Seyyah Bela Horvath Seyahatnamesine İlişkin Görsel s.82 (Ekoyay)

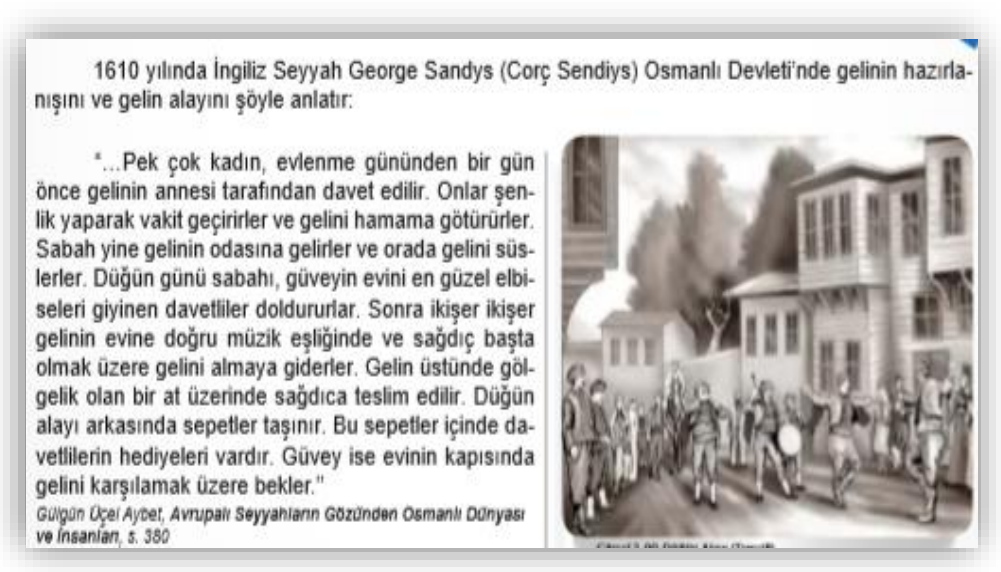

Görsel 14. 7. Sını 2. Ünite, Türk Tarihinde Yolculuk, Kültürümle Varım İçerisinde Seyyah George Sandays Seyahatnamesine İlişkin Görsel s.81 (MEB) 
Fransiz arkeolog ve çevirmen olan Gallan, Arapça, Farsça, Türkçe ve Ibranice dillerini

$10 . \quad$ öğrenmiştir. Osmanlı

Antoine Fransız elçisinin yanında Gallan bulunmuş ve Osmanlıyı gözlemleme firsatı bulmuştur. 'Bin Bir Gece Masalları' gibi pek çok eseri bulunmaktadır (Etensel, 2007).

Britanyalı arkeolog Charles Fellows, 1832 yılında İzmir'e taşınmıştır. İzmir'den yola çıkarak Anadolu'nun Batı Avrupa tarafından bilinmeyen 11. bölgelerine geziler Charles düzenlemiş ve araştırmalar Fellows yapmiştır. Yaptığı araştırmaları kayıt altına alarak bu bölgelerle ilgili bilinmeyenlere 1 şık tutmuştur (Kırca, 2010).

Bir İngiliz soylusu olan Keppel, askeri bir görev münasebetiyle ilk olarak Hindistan'a gönderilmiş, ardından Bakü, Astrakan, Moskova, St. Petersburg 12. güzergâhını takip ederek George İngiltere'ye varmıştır. Bu Thomas güzergâh üzerinde gezdiği Keppel yerleri buralarda yaşadıklarını yolculuğunu günlük olarak yayınlamıştır. Osmanlı-Rus savaşı sırasında Türkiye'ye gelerek İstanbul ve Edirne ziyaretlerinde bulunmuştur (Çetin, 2013).

Kanunî Sultan Süleyman döneminde İstanbul'da bulunan seyyah, Osmanlı ülkesine dair izlenimlerini 1557 yılında kaleme alarak

13. İspanya Kralı İkinci Philip'e

Manuel takdim etmiştir. Kitap Serrano Y. İspanya Kralının en büyük Sanz düşmanlarından olan Türkler hakkında krala bilgi vermek amaciyla yazılmıştır (Sanz, 2010).
XVII. yũzyllda yașamış Fransız Seyyah Antoine Gallan (Antuin Getin), hũsn-i hat ile ilgili gözlemini șôyle anlatir.

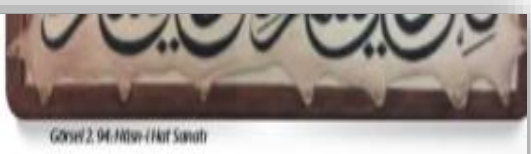

"Fransa Büyūkelçisi, Rûznâme adında daimi bir takvimi 2 kurușa satın aldı. Ișçlĭği o derece güzel, ince ve nazikti ki Fransa'da birçok sanatkâr eșini 10 kuruşa yapmayı istemez. Altın yaldızla ve renklerle tezyin edilmiş şekiller son derece güzel, ince, dakik ve isabetli çizimiş̧ti. Bundan daha güzel sanat eseri olması akla gelemezdi."

Yimaz Oztuna, BOyok Tonkye Tariml. 55.227 .22

Görsel 15. 7. Sinıf 2. Ünite, Türk Tarihinde Yolculuk, Kültürümle Vartm İçerisinde Seyyah Antoine Gallan Gözlemlerine İlişkin Görsel s.83 (MEB)

Batı Anadolu'yu gezen Ingiliz Seyyah Fellows (Fellovs), göçebe olarak yașayan ve hayvancilikla uğraşan Yörüklerin geleneksel oyunlarını izleme firsatı bulmuștur. Fellows, zeybek oyununun ağırllğ ve oynayanların eș zamanlı hareketleri konusundaki hayranliğıiı șu șekilde dile getirmiştir:

"Çok geçmeden bu ülkede her evde bulunan bir ut veya sazın sesi duyuldu. Ev sahiplerimizden bir delikanli; hepsi benzersiz fakat basit ve oldukça ahenkli pek çok ezgi çaldı. Daha sonra dans etmek için hayran kaldığımız ağır bir melodi çalmaya bașladı. Oradakiler bir daire olușturacak șekilde sıralandilar. Güvenliğimizi sağlayan korumamız, ortaya geçerek yörük veya çobanlara ait olduğunu söylediği benzersiz bir dansa bașladı. Bu dans oldukça yavaştı, figürler iyi çalışıılmış̧ı ve dans ederken yüz eksitililyordu."

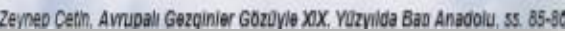

Görsel 16. 7. Sinıf 2. Ünite, Türk Tarihinde Yolculuk, Kültürümle Varım İçerisinde Seyyah Fellows Gözlemlerine İlişkin Görsel s.83 (MEB)

Görsel 17. 7. Sinıf 2. Ünite, Türk Tarihinde Yolculuk, Kültürümle Varım

Osmanl Devleti'ni ziyaret eden seyyahlardan Ingiliz Seyyah Keppele (Kepil) göre Türk insanının dürüstlüğü dikkat çekici bir konudur. Keppel, Türklerin dūrüstlüguüne dair șahit olduğu bir olayı șu șekilde anlatir:

1828 yilının kıș mevsiminde bir Türk postacl, yanında yüklü miktar sikkeyle uzak bir bölgeye gönderildi. Postacı, parayı teslim etmesi gereken yere vardığında para çantasını kaybettiğini fark etti. Para çantasıının sahibi Fransız, kendinden on beș bin kuruș istedi. Postacl, sakin șekilde dūşüñüūkten sonra geri dōndū ve parayı bir Müslüman'ın bulması hâlinde kendine geri vereceğinden emindi. Neredeyse bütün yolu tekrar gitti ve çaresiz bir șekilde, yolculuğu esnasinda birkaç dakika dinlendiğini hatılladığı bir kahvehaneye vardı. Kapıdaki kahveci ona șöyle bağırdl: 'Geçen geldiğinde içinde galiba altın olan bir çanta unutmussun, koyduğun yerde duruyor.' Postacı içeri girdi, bir Türk kahvehanesine gelen pek çok kișinin rahattlkla alabileceği șekilde ortada durmasina rağmen dokunulmamış görünen çantasııı buldu."

Zejnep Cesth, Avnupali Gozginler Gozuyle XXX. Yuzylloa Bav Anadalu, ss. 37.s8

İ̧erisinde Seyyah Keppel Gözlemlerine İlişkin Görsel s.80 (MEB)
Buraktilan hayratlar hang̨i çeq̣it oluru oloun bizdokindon fazladix. Bu yuizden yayarkon bilo bizdon

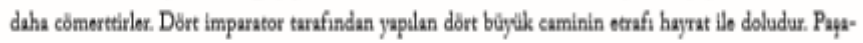

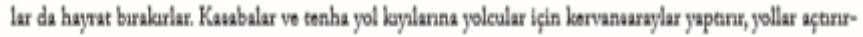

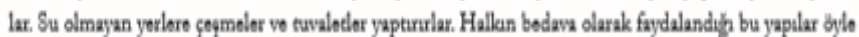
muhtopomdir ki oaraylara bentor. Buralardan istifado odenler "Allah yaperandas raza oloun." domoden odo-

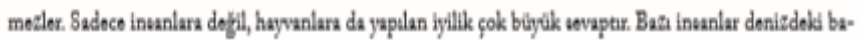
Lklara olomok atarlar.

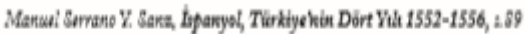

Görsel 18. 7. Sinıf 2. Ünite, Türk Tarihinde Yolculuk, Seyyahların Gözüyle Osmanlı İçerisinde Seyyah Manuel Serrano Y. Sanz Seyahatnamesine İlişkin Görsel s.89 (Ekoyay) 


\begin{tabular}{cl}
\hline & Bilinen tek mesleği \\
& gezginlik olan Jean \\
& Thevenot, öğretimini bitirir \\
& bitirmez 18 yaşında birçok \\
$\mathbf{1 4 .}$ & ülkeyi gezmiş, Türkiye'ye \\
Jean & de gelmiştir. Seyahatleri \\
Thevenot & sırasında notlar almış ve \\
& aldığı notları yayınlamıştır \\
& (Gürer, 2010).
\end{tabular}

Görsel 19. 7. Sinıf 2. Ünite, Türk Tarihinde Yolculuk, Seyyahlarn Gözüyle

Osmanl İçerisinde Seyyah Jean Thevenot Seyahatnamesine İlişkin Görsel s.85 (Ekoyay)
Fresne Canaye, Fransa'nın İstanbul Büyükelçisi Noailles sayesinde İstanbul'a gelme şansı elde etmiştir. Osmanlı ülkesinde Philippe de detaylarla anlatan seyyahın La Canaye izlenimleri, Türk kültürünün o dönemlerinin birinci ağıdan aktarılması ve bir yabancı gözüyle ele alınması açısından önemlidir (Canaye, 2017).
15. gördüklerini çok ince

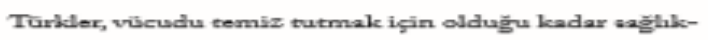
lax ipin de atk aule hamama giderles. Bu sebeple bu ullede bircolk güzel hamam vardux. Hepai de aym tarzda yapulmuglaxdux, bazalarinun diğerlerinden daha büyül veyz daha colc mermerle

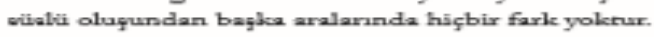
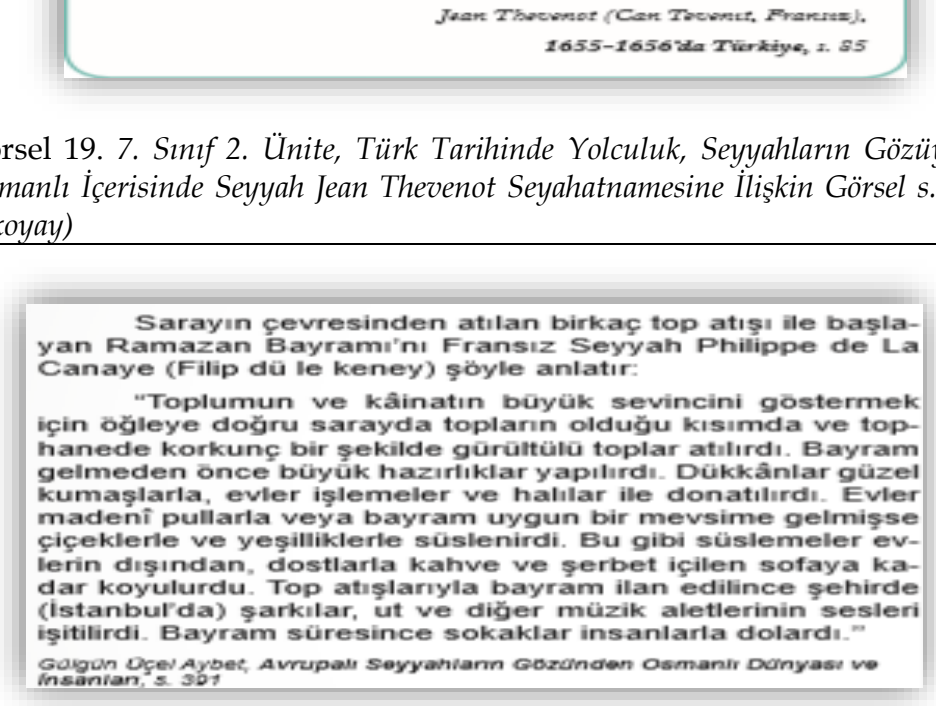

Görsel 20. 7. Sinıf 2. Ünite, Türk Tarihinde Yolculuk, Kültürümle Vartm İçerisinde Seyyah Philippe de la Canaye Seyahatnamesine İlişkin Görsel s.82(MEB)

16. Fransiz arkeolog, mimar ve

Charles gezgindir. Fransa

Texier tarafından Bayındırlık İşleri Müfettişliği görevi esnasinda Anadolu ve İran'a gönderilmiştir. Böylelikle bu ülkeleri gözlemleyip gezme firsatı bulmuştur. Anadolu seyahati sirasinda Hitit başkenti Hattuşa'yı keşfetmiştir (Yıldız, 2007).
Türklere ait en ōnemli el sanatlarından biri halıcllıktır. Türk hallları, Avrupalı birçok ressamın tablosuna da konu olmuștur. Fransız Seyyah Gezgin Charles Texier, (Çarls Teksie) Anadolu gezisi sırasında geldiği Manisa'nın Kula ilçesinde bu el sanatııı șu șekilde anlatır.

"Türkler, Rumlarla bir sanatı paylașırlar ki o da iyi bir geleceği olan Izmir halisıdır. Bu halllar, Amerika'ya kadar ihraç edilir. Yörūk kadınlan da çadırlarııın altında bu haliyı dokurlar. Bunlar ufak namaz seccadeleridir. Kula'da bol olan yün, boya veren bitkilerle birleșmiștir. Kırmızı, sarı, siyah renklerin ūretildiği așı boyası, kök boya, palamut ve kervanlarla gelen çivit, buradaki bu yerel sanatin ana maddesini sağlamıștir."

zeynep Çeth, Amupail Gezginiar Gozoylo XIX. Wuzyila Bav Anadolu, s. 34

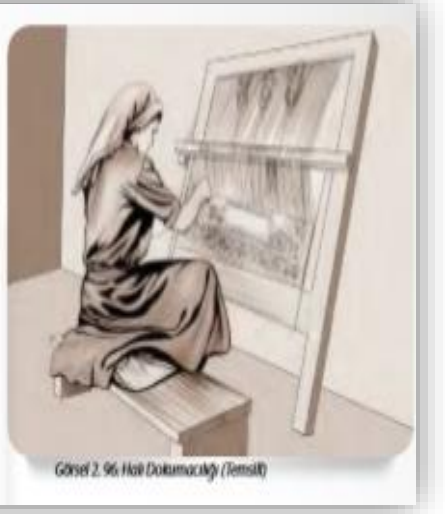

Görsel 21. 7. Sinı 2. Ünite, Türk Tarihinde Yolculuk, Kültürümle Varım İçerisinde Seyyah Charles Texier Gözlemlerine İlişkin Görsel s.84 (MEB)

Tablo 6 incelendiğinde; 2018 sosyal bilgiler öğretim programını içeren sosyal bilgiler 6. ve 7. sınıf ders kitaplarında; İbn-i Fadlan, Evliya Çelebi, İbn-i Battuta, Ogler Chirlain De Busbecq, Paul R. Krause, Stephan Gerlach, William Wittman, Bela Horvath, George Sandays, Antoine Gallan, Charles Fellows, George Thomas Keppel, Manuel Serrano Y. Sanz, Jean Thevenot, Philippe de La Canaye ve Charles Texier'e ilişkin bilgi ve bu seyyahların seyahatnamelerine ait metin örneklerinin görsellerine yer verildiği görülmektedir. Bu seyyahların ülkemizle bağlantılarını anlayabilmek adına haklarında bilgilere yer verme gereği hissedilmiştir. 


\section{Sonuç ve Tartışma}

Bu çalışmada elde edilen bulgulardan yola çıkılarak bir takım sonuçlar elde edilmiştir. Bu sonuçlara aşağıda yer verilmiştir.

2005 sosyal bilgiler öğretim programında seyahatnamelere ilişkin bulgulardan birtakım sonuçlara ulaşılmıştır. Elde edilen sonuçlara göre; 2005 sosyal bilgiler öğretim programında 4 . ve 5. sınıf öğrenme alanları içerisinde doğrudan seyahatname kullanımını içeren herhangi bir kazanıma yer verilmemiştir. Fakat 6. ve 7. sınıf öğrenme alanlarında ise 6. sınıf 'Kültür ve Miras' öğrenme alanı, 'İpek Yolunda Türkler' ünitesi altında 1. kazanım ile 7. sınıf 'Kültür ve Miras' öğrenme alanı, 'Türk Tarihinde Yolculuk' ünitesi altındaki 6. kazanımın doğrudan seyahatname kullanımını içeren kazanımlar olduğu belirlenmiştir. Öğretim programı içerisinde yer alan diğer kazanımlardan 12'sinin ise doğrudan seyahatname kullanımını içermediği fakat araştırmacılar tarafından seyahatname kullanımıyla ilişkilendirildiği sonucuna ulaşılmıştır. Ulaşılan bu durum aslında 2005 öğretim programı için seyahatname kullanımının sınırlandırılmadan daha geniş bir çerçevede de kullanılabileceği gerçeğini ortaya çıkarmıştır.

2005 sosyal bilgiler öğretim programına yönelik hazırlanan ders kitaplarının değerlendirilme sonuçlarına göre; 4. ve 5. sınıf öğretim programlarında doğrudan seyahatname kullanımını içeren kazanımlar bulunmadığı için ders kitaplarında da seyyah ve seyahatname örneklerine yer verilmediği, 6 . ve 7 . sinıf öğretim programlarında doğrudan seyahatname kullanımını içeren kazanımlar bulunduğu için de ders kitaplarında yerli ve yabancı 5 seyyah ve seyahatnamesine yer verildiği saptanmıştır. Sosyal bilgiler 6. sınıf ders kitabında 1 seyyaha ait metne rastlanırken, özellikle 7. sınıf ders kitabındaki "Seyyahlarla Gezinti" konusu altında 4 seyyaha ait metin örneklerine rastlanmıştır. Yakar (2013) tarafından yapılan tez çalışmasında da benzer sonuçlar yer almıştır. Ders kitaplarında genellikle tarih konuları içerisinde seyahatnamelerin kullanıldığı görülmüştür. Oruç ve Aygün (2018) tarafından yapılan çalışma sonuçları bu çalışmada elde edilen sonuçları desteklemektedir. Ders kitaplarında yer verilen seyahatname metinlerinin, öğretim programını destekler nitelikte hazırlandı̆̆ı ortaya çıkarılmıştır.

2018 sosyal bilgiler öğretim programında seyahatname kullanımına ilişkin bulgulardan elde edilen sonuçlara bakıldığında; 2018 sosyal bilgiler öğretim programında 4 . ve 5. sınıf öğrenme alanları içerisinde doğrudan seyahatname kullanımını içeren herhangi bir kazanıma yer verilmemiştir. 6. ve 7. sınıf öğrenme alanlarından ise 6. sınıf 'Kültür ve Miras' öğrenme alanı, 'İpek Yolunda Türkler' ünitesinin 1. kazanımı ile 7. sınıf 'Kültür ve Miras' öğrenme alanı, 'Türk Tarihinde Yolculuk' ünitesinin 5. kazanımı ve yine 7. sınıf ‘Üretim, Dağıtım ve Tüketim' öğrenme alanı, 'Ekonomi ve Sosyal Hayat' ünitesinin 4. kazanımının doğrudan seyahatname kullanımını içeren kazanımlar olduğu belirlenmiştir. 2005 öğretim programında seyahatnameler tarih konuları için kullanılmış olsa da 2018 öğretim programına gelindiğinde tarih konuları ve ekonomi ile ilişkili konular için de seyahatnamelerin kullanılabileceği, bu doğrultuda seyahatname kullanım alanlarının da genişlediği ve genişlemeye devam edeceği düşünülmektedir. Öğretim programı içerisinde yer alan diğer kazanımlardan 14'ünün ise doğrudan seyahatname kullanımını içermediği fakat araştırmacılar tarafından seyahatname kullanımıyla ilişkilendirildiği sonucuna ulaşılmıştır. Doğrudan verilen kazanımların yanında seyahatname kullanımı 
açısından ilişkilendirilen kazanımlar için de seyahatnamelerin kullanılmasının, derslerin kalıcılık ve verimliliğini artıracağı düşünülmektedir.

2018 sosyal bilgiler öğretim programına yönelik hazırlanan ders kitaplarının değerlendirilme sonuçlara bakıldığında; 4. ve 5. sınıf öğretim programlarında doğrudan seyahatname kullanımını içeren kazanımlar bulunmadığı için ders kitaplarında da seyyah ve seyahatname örneklerine yer verilmediği belirlenmiştir. 6 . ve 7. sınıf öğretim programlarında ise doğrudan seyahatname kullanımını içeren kazanımlar bulunduğu için ders kitaplarında da yerli ve yabancı 16 seyyah ve seyahatname örneğine yer verildiği saptanmıştır. Buradan yola çıkarak öğretim programları ve ders kitaplarının birbirlerini tamamlayıcı niteliklerde olduğu söylenebilir. Özellikle 7. sinıfta "Seyyahların Gözünden Osmanlı Kültürü" isimli konuda farklı dönemlerdeki seyahatname örneklerine yer verildiği görülmüştür. Çelik ve Çetin (2019)' in tez çalışması da ulaşılan sonuçları destekler niteliktedir. Yeşilbursa ve Sabancı'nın (2015) yapmış olduğu çalışmada ise; sosyal bilgiler programında edebi ürünlerin en çok tarih, coğrafya gibi disiplinlerini içeren konularda kullanıldığı ortaya çıkarılmış ve bu sonuçlarla yapılan çalışma sonuçlarının örtüştüğü gözlenmiştir.

Tüm bu sonuçlardan yola çıkarak; 2005 öğretim programına göre 2018 öğretim programında seyahatname kullanımının ciddi bir artışı söz konusu olmasa da belli bir artışın olduğu ve bu artışın ders kitaplarına da yansıdığı ortaya çıkarılmıştır. Ayrıca seyahatname kullanımını uygun gören kazanımların sayıca fazla olmasinın seyahatnamelerin kullanım alanlarını artırılabileceği ve bu durumun seyahatnamelerin önemini artırdığı söylenebilir. Çünkü seyahatnameler, yeterli bilginin bulunmadığ 1 durumlarda öğrencilere 1şık tutarak birincil kaynak niteliğinde kullanıldıkları ve kullanılmaya devam edecekleri için değeri ve öneminin özellikle son yıllarda farkına varıldı ğı düşünülmektedir.

\section{Öneriler}

1. Nitel araştırma olarak tasarlanan bu çalışmanın ölçek veya anket kullanılarak nicel boyutu da ele alınabilir.

2. 2005 ve 2018 sosyal bilgiler öğretim programlarında seyahatname kullanımı öğretmen görüşleri açısından da değerlendirilebilir.

3. 2018 sosyal bilgiler öğretim programlarında seyahatname kullanımı ile ilişkilendirilen kazanımlar için seyahatname kullanmanın faydalarına yönelik çalışmalar yapılabilir.

4. 2018 sosyal bilgiler öğretim programında seyahatnamelerle ilişkilendirilen 14 kazanım için sosyal bilgiler öğretmenleri seyahatnamelere yer vererek ders etkililiğini artırabilirler.

5. Sosyal bilgiler öğretim programında yer verilen araç-gereçler listelerinde, seyahatnameler de dâhil edilebilir. 


\section{Kaynakça}

Altıntaş, M. (2019). İbn Battûta'ya göre Anadolu şehirlerinde siyâŝ̂, dinî, ilmî, içtimâî ve iktisâdî hayat, (Yayınlanmamış Yüksek Lisans Tezi), İstanbul Üniversitesi Sosyal Bilimler Enstitüsü, İstanbul.

Arıkan, R. (2011). Araştırma yöntem ve teknikleri. (genişletilmiş 2. baskı). Ankara: Nobel Akademik Yayıncilik.

Arıkan, Z. (2003). Robert Mantran. İslam Ansiklopedisi, (Cilt: 28, ss. 30-31) İstanbul: Türkiye Diyanet Vakfı Yayınları. 2https:/ / islamansiklopedisi.org.tr/muellif/ 28.03.2020 tarihinde erişim sağlanmıştır.

Ata, B. (2013). Sosyal bilgiler öğretim programı ve seyahatnameler: "Çocuklar, ninelerimiz ve dedelerimiz çok yardımseverdi". Türk Yurdu Dergisi, 30, 164166.

Aykaç, N. (2007). İlköğretim sosyal bilgiler dersi eğitim-öğretim programına yönelik öğretmen görüşleri. Elektronik Sosyal Bilimler Dergisi, 6(22), 46-73. https:// dergipark.org.tr/tr/download/article-file/69992.

Beldağ, A. ve Aktaş, E . (2016). Sosyal bilgiler öğretiminde edebî eser kullanımı: Nitel bir çalışma. Erzincan Üniversitesi Eğitim Fakültesi Dergisi, 18(2) , 953-981. https:// doi.org/10.17556/jef.72887.

Busbecq, O.G. (2005). Türk mektuplarl, kanuni döneminde Avrupalı bir elçinin gözlemleri (1555-1560), (Çev: Derin Türkömer), İstanbul: Türkiye İş Bankası Kültür Yayınlar1.

Canaye, P.F. (2017). Fresne - Canaye seyahatnamesi 1573, (Çev: Teoman Tunçdoğan), İstanbul: Kitap Yayınevi.

Çelik, A. (2016), Sosyal bilgiler dersi öğretiminde Evliya Çelebi seyahatnamesi'nin kullanımı, (Yayınlanmamış Doktora Tezi), Gazi Üniversitesi Eğitim Bilimleri Enstitüsü, Ankara.

Çelik, A. ve Çetin, T. (2019). Sosyal bilgiler dersi öğretiminde Evliya Çelebi seyahatnamesi' nin kullanımı. Manas Sosyal Araştırmalar Dergisi, 8(3), 23362359. https:/ / doi.org/10.33206/ mjss.518282.

Çetin, Z. (2013). Avrupalı gezginler gözüyle 19. yüzyılda Batı Anadolu, (Yayınlanmamış Yüksek Lisans Tezi), Adnan Menderes Üniversitesi Sosyal Bilimler Enstitüsü, Aydin.

Çetişli, İ. (2006). Edebiyat eğitiminde edebî metnin yeri ve anlamı. Millî Ĕ̆itim Dergisi, 34(169). https:/ / dergipark.org.tr/tr/download/article-file/ 470207

Ellison, J. (2002). George Sandys: travel, colonialism and tolerance in the 17th century, First Published, Cambridge: D.S. Brewer.

Etensel, A. İ. (2007). "Bir yazın türü olarak doğu seyahatnameleri”, Littera, c. 21, http:/ / www.littera.hacettepe.edu.tr/TURKCE/21_cilt/ildem.pdf 15.04.2020 tarihinde erişim sağlanmıştır.

Eyice, S. (1975). Bertrandon de la Broquière ve seyahatnâmesi. İslam Tetkikleri Enstitüsü Dergisi, 6, 85-126. https:/ / dergipark.org.tr/tr/download/articlefile/13083

Gerlach, S. (2010). Türkiye günlü̈̆̈̈̈, (Çev. Türkis Noyan ), İstanbul: Kitap Yayınevi. Gündüz, N. (2019). Bir kadın seyyahın kaleminden Osmanlı'da 18. yüzyıl saraylı kadın erkek giysileri: bir kültürü tanımak. Millî Folklor Dergisi, 124, 121-135. https:// dergipark.org.tr/tr/download/article-file/907519 
Gürer, S. (2010). XVII-XVIII ve XIX. yüzyıllarda Fransız seyahatnamelerinde Osmanlı toplumu. (Yayınlanmamış Doktora Tezi), Ankara Üniversitesi Sosyal Bilimler Enstitüsü, Ankara.

Horvath, B. (2010). Anadolu 1913, (Çev: Tarık Demirkan), Ankara: Tarih Vakf1 Yurt Yayınları.

İlhan, G. O. (2016). Sosyal bilgiler öğretiminde çizx gi romanların kullanımı. (Yayınlanmamış Doktora Tezi), Afyon Kocatepe Üniversitesi Sosyal Bilimler Enstitüsü, Afyonkarahisar.

Kahraman, S. A. (2013). Evliya Çelebi ile devr-i alem. Ankara: Türk Dil Kurumu Yayınlar1.

Kırca, H. S. (2010). Ingiliz seyyah Sir Charles Fellows'un eserlerinde Türkiye ve Türk imajı. (Yayınlanmamış Yüksek Lisans Tezi), Süleyman Demirel Üniversitesi Sosyal Bilimler Enstitüsü, Isparta.

Krause, P.R. (2005). Türkiye 1915, (Çev: Nurettin Süleymangil), İstanbul: Heyamola Yayınlar1.

Kurşun, Z. (2012). Seyyah-ı alem Evliya Çelebi. Çoşkun Yılmaz (Ed.), Evliya Çelebi Atlası içinde, 86-91, MEDAM, İstanbul: Mahya.

Maden, S. (2008). Türk edebiyatında seyahatnameler ve gezi yazıları, travelbook and 1tinerary in Turkish literature, A.Ü. Türkiyat Araştırmaları Enstitüsü Dergisi, 37, 147-158.

http:/ / www.turkiyatjournal.com/Makaleler/1586163345_Sedat\%20MADEN. pdf

Mc Gowan, T. ve Guzzetti, B. (2003). Edebiyat temelli sosyal bilgiler öğretimi. A. Doğanay (çev.). Çukurova Üniversitesi Sosyal Bilimler Enstitüsü Dergisi, 11 (11), https:// dergipark.org.tr/tr/pub/cusosbil/issue/4367/59729 10.04.2020 tarihinde erişim sağlanmıştır.

MEB (2005). Sosyal Bilgiler Öğretim Programı (4-5 ve 6-7). http:/ /ttkb.meb.gov.tr/program2.aspx adresinden 31.05.2020 tarihinde indirilmiştir.

Oruç, Ş. ve Aygün, M. (2018). Sosyal bilgiler ders kitaplarında seyahatnameler, Uluslararası Ders Kitapları ve Eğitim Materyalleri Dergisi, 1 (1), 46-57. https:// dergipark.org.tr/tr/download/article-file/587799

Öztürk, C. (2009). Sosyal bilgiler: toplumsal yaşama disiplinler arası bir bakış, C. Öztürk, (Ed.), Sosyal Bilgiler Öğretimi Demokratik Vatandaşlık Eğitimi içinde, 2-31, Ankara: Pegem Akademi.

Sanz, M.S.Y. (2010). Türkiye'nin dört yılı 1552 - 1556, (Çev: Ahmet Kurutluoğlu), İstanbul: Tercüman Yayınları.

Şeşen, R. (2012). İbn-i Fadlan seyahatnamesi, (3. Bask1), İstanbul: Yeditepe Yayınevi.

Şimşek, A. (2006). İlköğretim sosyal bilgiler dersinde tarihsel hikâyeye yönelik öğrenci görüşleri, Gazi Ĕ̆itim Fakültesi Dergisi, 26(1), 187-202. http:/ / www.gefad.gazi.edu.tr/tr/download/article-file/77220

Şimşek, A. (2015). Sosyal bilgiler derslerinde bir öğretim materyali olarak edebi ürünler. M. Safran, (Ed.), Sosyal Bilgiler Öğretimi (4. baskı) içinde, 390-409. Ankara: Pegem Akademi. 
Şirin, İ. (2020). Seyahatnamelerin sosyal bilimlerde kullanım değeri: Seyahatname metodolojisi geliştirmenin zorunluluğu, Türk Yurdu Dergisi, 30, 53-58.

https:/ / www.turkyurdu.com.tr/yazar-yazi.php?id=760

Uygur, E. (2006). Jean potocki ve kafkasya seyahatnamesi, Modern Türk Araştırmaları Dergisi, 3(2), 29-37. http:/ / mtad.humanity.ankara.edu.tr/III-

2_Haziran2006/23_MTAD_3-2_EUygur.pdf

Yakar, H. (2013). Cumhuriyetten günümüze uygulanmış olan ilköğretim sosyal bilgiler ögretim programlarında seyahatnamelerin incelenmesi. (Yayınlanmamış Yüksek Lisans Tezi), İnönü Üniversitesi Eğitim Bilimleri Enstitüsü, Malatya.

Yancı, Ü. (2016). Batılıların gözünde osmanlı kadını imajı üzerine bir değerlendirme, Akademik Sosyal Araştırmalar Dergisi, 23, 381-396. DOI : 10.16992/ ASOS.1039

Yazıc1, H. (2009). Seyahatname, İslam Ansiklopedisi (Cilt 37, ss. 9-11) İstanbul: Türkiye Diyanet Vakfı Yayınları.

Yeşilbursa, C. C., ve Sabancı, O. (2015). Sosyal bilgiler öğretmen adaylarının sosyal bilgiler öğretiminde edebi ürünlerin kullanımına yönelik görüşleri. Mehmet Akif Ersoy Üniversitesi Ĕ̈itim Fakültesi Dergisi, 36, 19-33. https:/ / dergipark.org.tr/tr/download/article-file/181507

Yıldırım, A., ve Şimşek, H. (2011). Sosyal bilimlerde nitel araştırma yöntemleri (8th ed.), Ankara: Seçkin Yayınevi.

Yıldız, M. (2007). Fransız gezgin Charles Texier'in Küçük Asya'sının Anadolu kültür tarihindeki yeri, EKEV Akademi Dergisi, 11(31), 171-178.

Wittman, W. (1803) Travels in Turkey, Asia minor, Syria and across the desert into Egypt during the years 1799, 1800 and 1801 in company with The Turkish army, and The British military mission, printed for richard phillips, No: 71, London: St. Paul's Church Yard.

\section{Summary}

\section{Introduction}

Social studies; It is a curriculum aiming to teach life-oriented knowledge by making use of social sciences such as literature, law, sociology, psychology, anthropology, history, geography, economics and political science (MEB, 2005). The main purpose of the social studies course curriculum; It is to provide individuals with knowledge, skills, values and attitudes about citizenship issues. Various methods, techniques and materials have been used for this purpose. Oral and written literary works such as travel books, epics, stories, fairy tales and inscriptions are also considered among these materials. With the use of literary products in lessons, in students; Understanding, interpretation, empathy skills are developed, and behaviors of analyzing and developing different perspectives are also acquired. Travel books are one of the literary products that are required to be used in social studies course. With the use of the travel books in the lesson process, the subject covered is concretized and the subject is more easily understood by the student. The aim of this research is to determine the use of travel books in social studies curricula and social studies textbooks in 2005 and 2018 and to understand the exchange between programs. It is thought that determining the changes in travel book use cases in textbooks according to the 2005 and 2018 social studies curricula will contribute to the field. 


\section{Method}

In this study, it was aimed to determine the use cases of travel books in social studies teaching programs and social studies textbooks in 2005 and 2018, and this study was designed in qualitative research design and carried out with descriptive research method.

Document review method was used at the stage of collecting study data. For the study data, the 2005-2018 social studies course curriculums were approved by the Ministry of National Education (MEB), and the social studies 6th and 7th grade textbooks of the Ministry of Education and Ekoyay publications in the specified years and again belong to the Ministry of Education and Anittepe publications. Social studies 6th and 7th grade textbooks of 2010 and 2013 were used as documents.

The data obtained through the document analysis were examined using the descriptive analysis method. In this context, 2005-2018 social studies curricula and the textbooks created for these programs were examined.

\section{Results}

Some conclusions were drawn from the findings of the travel books in the 2005 social studies curriculum. According to the results obtained; In the 2005 social studies curriculum, it was determined that there was no acquisition involving the use of direct travel book in the 4th and 5th grade learning areas, while the two acquisitions in the 6th and 7th grade learning areas included direct travel book use. It was concluded that 12 of the other acquisitions in the curriculum did not include the use of travel book directly, but were associated with the use of travel book by the researchers. This situation has actually revealed the fact that the use of travel books for the 2005 curriculum can be used in a wider framework without restricting it.

According to the results of the evaluation of the textbooks prepared for the 2005 social studies curriculum; It has been determined that there are no traveler and travel book examples in the 4th and 5th grade textbooks, while the 6th and 7 th grade curriculums include 5 local and foreign travelers and their travel book. It has been revealed that the travel book texts in the textbooks are prepared in a way that supports the curriculum.

Considering the results obtained from the findings on the use of travel accounts in the 2018 social studies curriculum; The 2018 social studies curriculum did not include any acquisitions that involve the use of direct travel books within the 4th and 5 th grade learning areas. Three acquisitions from the 6th and 7th grade learning areas were determined to be those involving direct travel book use. Although travel books were used for history subjects in the 2005 curriculum, it is thought that travel books can also be used for subjects related to history and economics when it comes to the 2018 curriculum, and in this direction, the use of travel books will expand and continue to expand. It was concluded that 14 of the other acquisitions in the curriculum did not include the use of travel book directly, but were associated with the use of travel book by the researchers. It is thought that the use of travel books for gains associated with the use of travel book besides the direct gains will increase the permanence and efficiency of the lessons.

Considering the results of the evaluation of the textbooks prepared for the 2018 social studies curriculum; It has been determined that there are no examples of traveler and travel books in the 4th and 5th grade textbooks, and 16 local and foreign travelers 
and travel book samples are included in the 6th and 7th grade textbooks. Based on this, it can be said that curricula and textbooks are complementary to each other.

Based on all these results; According to the 2005 curriculum, although there was no significant increase in the use of travel books in the 2018 curriculum, it was revealed that there was a certain increase and this increase was also reflected in the textbooks. In addition, it can be said that the high number of gains that deem it appropriate to use travel books may increase the usage areas of travel books and this situation increases the importance of travel books.

\section{Discussion}

According to the study, the use of the travel book in the curriculum and the use of the travel book texts in the textbooks were found to support each other. The thesis study by Yakar (2013) and the studies of Oruç and Aygün (2018) support the findings of the study. Another result of the study is that in the social studies program, literary works are mostly used in subjects including history and geography. It was observed that the study of Yeşilbursa and Sabancı (2015) coincided with these results.

\section{Pedagogical Implications}

Studies can be conducted on the benefits of using travel books for the acquisitions associated with the use of travel accounts in 2018 social studies curricula. In the 2018 social studies curriculum, social studies teachers can increase the effectiveness of the lesson by including travel books for 14 acquisitions associated with travel books.

\section{Araştırmanın Etik Taahhüt Metni}

Yapılan bu çalışmada bilimsel, etik ve alıntı kurallarına uyulduğu; toplanan veriler üzerinde herhangi bir tahrifatın yapılmadığı, karşılaşılacak tüm etik ihlallerde "Cumhuriyet Uluslararası Eğitim Dergisi ve Editörünün" hiçbir sorumluluğunun olmadığı, tüm sorumluluğun Sorumlu Yazara ait olduğu ve bu çalışmanın herhangi başka bir akademik yayın ortamına değerlendirme için gönderilmemiş olduğu sorumlu yazar tarafından taahhüt edilmiştir.

\section{Authors' Biodata/Yazar Bilgileri}

Ülkü YANCI, Sivas Cumhuriyet Üniversitesi Eğitim Fakültesi Türkçe ve Sosyal Bilimler Eğitimi Bölümü'nde öğretim üyesi olarak görev yapmaktadır.

Ülkü Yancı works an associate professor at Sivas Cumhuriyet University, Faculty of Education, Department of Turkish and Social Sciences Education.

Nagihan EVCİ, Cumhuriyet Üniversitesi, Eğitim Bilimleri Enstitüsü, Sosyal Bilgiler Eğitimi Anabilim Dalı'nda doktora öğrencisidir.

Nagihan Evci is a PhD student at the Department of Social Studies Education in Sivas Cumhuriyet University. 